\title{
Relationship between angiotensin-converting enzyme inhibitors, angiotensin II receptor blockers and SARS-CoV-2 infection: where are we?
}

\author{
Fabio INFUSINO $1 *$, Sara CIMINO 1, Marco LOMBARDI 2 , \\ Massimo MANCONE 1, Elena CAVARRETTA 3, 4, Giacomo FRATI 3, 5, \\ Francesco PUGLIESE ${ }^{6}$, Francesco FEDELE ${ }^{1}$, Giuseppe BIONDI ZOCCAI 3,4
}

\begin{abstract}
${ }^{1}$ Department of Clinical Internal, Anesthesiologic and Cardiovascular Sciences, Sapienza University, Rome, Italy; 2Department of Cardiovascular and Thoracic Sciences, Sacred Heart Catholic University, Rome, Italy; ${ }^{3}$ Department of Medico-Surgical Sciences and Biotechnologies, Sapienza University, Latina, Italy; ${ }^{4}$ Mediterranea Cardiocenter, Naples, Italy; 5IRCCS NEUROMED Institute, Pozzilli, Isernia, Italy; ${ }^{6}$ Paride Stefanini Department of General Surgery and Surgical Specialties, Sapienza University, Rome, Italy

*Corresponding author: Fabio Infusino, Department of Clinical Internal, Anesthesiologic and Cardiovascular Sciences, Sapienza University, Viale del Policlinico 155, 00186 Rome, Italy. E-mail: fabio.infusino@uniroma1.it
\end{abstract}

\section{A B S T R A C T}

In recent months SARS-CoV-2 has spread rapidly throughout the world. The case fatality rate is higher in cardiovascular disease and hypertension. Other comorbidities do not seem to confer the same risk, therefore the understanding of the relationship between infection and cardiovascular system could be a crucial point for the fight against the virus. A great interest is directed towards the angiotensin 2 converting enzyme (ACE 2) which is the SARS-CoV-2 receptor and creates important connections between the virus replication pathway, the cardiovascular system and blood pressure. All cardiovascular conditions share an imbalance of the renin angiotensin system in which ACE 2 plays a central role. In the early pandemic period, much confusion has appeared about the management of therapy with angiotensin converting enzyme inhibitors and angiotensin receptor blockers especially in infected patients and in those at risk of critical illness in case of infection. In this article we will try to reorder the major opinions currently emerging on this topic.

(Cite this article as: Infusino F, Cimino S, Lombardi M, Mancone M, Cavarretta E, Frati G, et al. Relationship between angiotensin-converting enzyme inhibitors, angiotensin II receptor blockers and SARS-CoV-2 infection: where are we? Minerva Cardioangiol 2020;68:339-46. DOI: 10.23736/S0026-4725.20.05271-8)

KEY WORDS: COVID-19; Angiotensin-converting enzyme inhibitors; Cardiovascular diseases.

$\mathrm{S}$ evere acute respiratory syndrome coronavirus 2 (SARS-CoV 2) has spread rapidly throughout the world ${ }^{1}$ and many scientists are making several efforts to reduce mortality of coronavirus disease-19 (COVID-19).

The case fatality rate (CFR) seems higher in some patients, in particular among those with preexisting comorbidities, such as cardiovascular disease (CVD) (10.5\%). Heart and Lung are closely tied, it is well known that pathological changes in lung parenchyma occurring in acute distress respiratory syndrome (ARDS) affect heart-lung interaction and could lead to worse consequences in patients with CVD. However, even patients with isolated hypertension have a high CFR $(6 \%)$ which appears greater than cancer patients $(5.6 \%){ }^{2}$

Since angiotensin-converting enzyme (ACE 2) has been identified as a SARS-CoV-2 receptor, ${ }^{3-5}$ there has been a great deal of confusion about the relationship between the infection and 


\section{COPYRIGHT $^{\circledR} 2020$ EDIZIONI MINERVA MEDICA}

all those conditions that alter the renin-angiotensin-aldosterone system (RAAS) such as cardiovascular diseases and antihypertensive drugs.

Many doctors are still wondering how ACEinhibitors (ACE-i) and angiotensin II receptor blockers (ARBs) should be managed in patients infected with SARS-CoV-2 and in those at risk of infection. In this article we will try to review the major opinions currently emerging on this topic.

\section{RAAS physiopathology}

RAAS is a hormonal regulator of blood volume and systemic vascular resistance, involving kidneys, lungs, systemic vasculature, and the brain. ${ }^{6}$

The angiotensin 1 converting enzyme (ACE) cleaves angiotensin I to generate angiotensin II, the peptide which binds to and activates angiotensin receptor subtype $1\left(\mathrm{AT}_{1}\right)$, resulting in vessel constriction. On the contrary, ACE 2 inactivates angiotensin II while generating angiotensin 1-7, a heptapeptide with strong vasodilator effect via activation of its Mas receptor, acting as a negative regulator of the renin-angiotensin system $^{7-9}$ (Figure 1).

Furthermore, it was previously postulated that, in the ARDS, ACE, angiotensin II, and angiotensin II receptor $\mathrm{AT}_{1}$, promote the disease pathogenesis, whereas ACE 2 and the angiotensin II receptor $\mathrm{AT}_{2}$ protect from ARDS. 10

\section{ACE 2-SARS-CoV-2 interaction}

SARS-CoV-2 infection results from the interaction between the spike protein $(\mathrm{S})$ of the virus

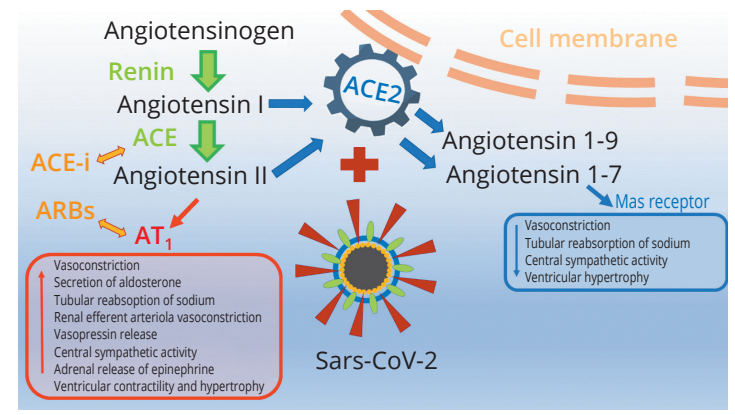

Figure 1.- Role of ACE2 as renin angiotensin system regulator and SARS-CoV-2 binding site.

ACE: Angiotensin converting enzyme; ACE-i: angiotensin converting enzyme inhibitors; ARBs: angiotensin receptor blockers; AT1: angiotensin receptor subtype 1; SARSCoV-2: severe acute respiratory syndrome Coronavirus 2 . to ACE 211, which is highly expressed in the heart and lungs, blood vessels, epithelial cells of kidney and intestine. ${ }^{12,} 13$ Some authors hypothesized that SARS-CoV causes robust downregulation of cellular ACE 2 expression levels, and it has been suggested that this mechanism is involved in the severity of disease. 14

Importantly, during SARS-CoV emergency in 2003, some studies already showed the important role of ACE 2 and RAAS in acute lung injury (ALI) due to SARS-CoV infection. ${ }^{3} \mathrm{Au}-$ thors demonstrated a reduced ACE 2 expression induced by virus and an attenuation of acute lung failure by blocking RAAS pathway in mice. ${ }^{3}$

\section{ACE 2 and inflammation}

In the above-mentioned paper by Imai et al., ${ }^{10}$ authors demonstrated that loss of ACE 2 expression in mutant mice resulted in enhanced vascular permeability, increased lung edema, neutrophil accumulation, and worsened lung function. Importantly, treatment with catalytically active recombinant ACE 2 protein improved the symptoms of ALI in both the wild type and ACE 2 knockout mice.

Furthermore, it was hypothesized that ACE 2 activity may influence endotoxin-induced desArg9 bradykinin (DABK)/B1 receptor signaling and neutrophil infiltration. ${ }^{15}$ Authors demonstrated that, after the exposure to inflammatory stimuli, ACE 2 activity is impaired, activating the DABK/BKB1R axis. This mechanism promotes the production and release of chemokines from airway epithelial cells, which recruit neutrophils to the lung. Authors demonstrated this mechanism in mice, after loss of ACE function due to endotoxin inhalation.

Moreover, in another previously published work conducted on mice with lipopolysaccharide (LPS)-induced ALI, expression of ACE 2 was reduced, while an overexpression of $\mathrm{ACE}$ 2 regulates the ACE2/Ang-(1-7)/Mas and ACE/ Ang II/AT ${ }_{1}$ axes to balance the RAAS and attenuate inflammatory response. ${ }^{16}$

From this point of view, ACE 2 seems to have a role in reducing inflammation and it has been suggested that modulating its expression could be considered as a potential therapeutic strategy for inflammatory lung diseases. 


\section{COPYRIGHT $^{\circledR} 2020$ EDIZIONI MINERVA MEDICA}

ACE-INHIBITORS, ARBS AND SARS-COV-2

INFUSINO

Recently, starting from biological evidence suggesting that ACE-i may increase the risk of lung cancer through the accumulation of bradykinin and substance $\mathrm{P}$ in the lung, it has been demonstrated that the use of ACE-i was associated with a $14 \%$ increased risk of lung cancer. ${ }^{12}$

\section{ACE 2: localization and genetic polymorphism}

ACE 2 expression in human tissues and apparatus

Even though ACE 2 is expressed on lung alveolar epithelial cells, enterocytes, endothelial cells of the blood vessels and arterial smooth muscle cells, ${ }^{17}$ its spike protein-binding site is mainly concentrated in type II alveolar cells (AT2), which in turn express many other genes that code for positive regulators of viral replication and transmission. ${ }^{18}$ Interestingly, as previously demonstrated by Jia and colleagues, ${ }^{19}$ ACE 2 expression correlates with the differentiation state of epithelia, being more expressed on the apical surface of polarized airway epithelia. Moreover, authors demonstrated that, undifferentiated cells expressing little levels of ACE 2 were barely infected with SARS-CoV, differently from welldifferentiated cells.

\section{ACE 2 genetic polymorphism (race and gender)}

Considering the high variability of ACE 2 expression in different human tissues that reflects differences in their susceptibility to the infection, it was hypothesized that specific ACE 2 variants could reduce the association with $\mathrm{S}$ viral binding protein, ${ }^{20}$ and thus, genetic polymorphisms could determine different grades of susceptibility. Zhao et al., ${ }^{18}$ using single-cell RNA analysis, previously demonstrated that Asian male have a higher ACE 2 expression cell ratio than Caucasian and African-Americans; while Cai, ${ }^{21}$ using a RNA seq and micro array, indicated the absence of significant gender and race difference. Cao et al. ${ }^{22}$ analyzed the coding-region variants in ACE 2 gene and the allele frequencies (AFs) expression from the China Metabolic Analytics Project (ChinaMAP) and 1000 Genomes Project (1KGP) databases. Authors did not find any proof of the existence of natural resistant variants for viral S-protein binding but differences in AFs distribution, probably related with a potential variability of ACE2 expression in different populations and ethnics in Asia. These results deserve further research in order to confirm ACE 2 role in ALI pathogenesis and a different susceptibility to SARS-CoV-2 infection among different populations. ${ }^{23}$ However, the genetic assumptions underlying the differences in ACE 2 expression and function in different populations are still unknown.

For what concerns gender differences, some studies have shown how genetic differences of ACE 2 can be associated with a different cardiovascular risk, for some alleles only in women ${ }^{24}$ for others in both sexes. ${ }^{25}$ Other studies have shown that different ACE 2 alleles are associated with a hypertensive phenotype in different ethnicities. ${ }^{26}$ The ACE 2 allele maps to the $\mathrm{X}$ chromosome, in an area that seems to escape random inactivation, a process that balances the gene expression linked to the $\mathrm{X}$ chromosome in women. ${ }^{27}$

For this last reason and for other gender differences mentioned above, the hypothesis that ACE2 is among those responsible for gender differences in hypertension and ischemic heart disease cannot be excluded.

The COVID-19 CFR is now showing gender differences, with higher mortality in males. ${ }^{2}$ Also, in this context it cannot be excluded that ACE 2 is implicated in the gender difference that characterizes the severity of the disease in case of SARS-CoV-2 infection. However, there are currently no studies examining this possibility.

\section{ACE 2 and smoke habit}

The above-mentioned paper by $\mathrm{Cai}^{21}$ observed a significantly higher ACE 2 gene expression in smokers as compared with non-smoker. The mechanism involved in this altered expression of ACE 2 is still unknow, but authors postulated that smokers may be more susceptible to COVID-19, and that smoking history should be considered in identifying susceptible subjects. The main limitation of the mentioned study was that the analyzed data were from the normal lung tis- 


\section{COPYRIGHT $^{\circledR} 2020$ EDIZIONI MINERVA MEDICA}

INFUSINO

ACE-INHIBITORS, ARBS AND SARS-COV-2

sue of patients with lung adenocarcinoma, which may be different with the lung tissue of healthy people.

\section{ACE 2 activity and drugs}

ACE-i and angiotensin receptor blockers (ARBs) are widely employed in patients with arterial hypertension, heart failure and kidney disease. ${ }^{28}$ Although both classes of drugs act on the RAAS, ACE-i inhibit the formation of angiotensin II and consequently the downstream effects mediated by both angiotensin II $\mathrm{AT}_{1}$ (vasoconstriction, cell growth, sodium and water retention, sympathetic activation) and angiotensin II $\mathrm{AT}_{2}$ receptor. The non-selective inhibition of angiotensin receptors inhibits the breakdown of bradykinin and increases circulating bradykinin levels; this mechanism is involved in the pathogenesis of ACE- $i$ induced cough and angioedema. ${ }^{29}$ Conversely, ARBs have the specific effect of displacing angiotensin II from the $\mathrm{AT}_{1}$ receptor and their associated autocrine cascade with bradykinin, nitric oxide, and vasoactive prostaglandins is considerably less important than that occurring with ACE-i.

\section{From the laboratory bench to the patient's bedside}

Since it has been demonstrated that the binding of the SARS-CoV S protein to ACE 2 leads to ACE 2 downregulation, ${ }^{3}$ which results in an overproduction of angiotensin by ACE, it was postulated that this mechanism contributes to lung injury, because of an increased pulmonary vascular permeability due to a lower production of angiotensin $1-7$ by ACE 2.30

Starting from the hypothesis regarding their anti-inflammatory effect, drugs causing ACE 2 up-regulation could be considered as protective. Ferrario et al. ${ }^{30}$ in 2005 studied a population of Lewis rats, 12 days after continuous administration of lisinopril, losartan or both, and demonstrated that selective blockade of either angiotensin II synthesis or activity, induced increases in ACE 2 gene expression and ACE 2 activity. Moskowitz et al. in $2004{ }^{31}$ postulated that both ACE-i and ARBs might be considered as general viral antidotes, thanks to the attenuation of the cytokine in viral diseases. Recently, some authors hypothesized that, more specifically, angiotensin receptor $1\left(\mathrm{AT}_{1}\right)$ inhibitors might be beneficial for patients infected by COVID-19 who develop pneumonia, $32-34$ thanks to the demonstrated up-regulation of ACE 2 expression following chronic treatment (28 days) in rats. ${ }^{35}$ Indeed, as underlined above, ARBs not only are related with ACE 2 up-regulation, but, unlike ACE-i, they do not seem to be associated with increased bradykinin levels.

Conversely, considering that, as described above, ACE2 is the binding site for SARSCoV-2, the suggestion to treat COVID-19 patients with ARBs for their associated ACE2 upregulation seems counter-intuitive. The expression of ACE 2 is relatively limited in healthy subjects, but it is increased in diabetics, ${ }^{36}$ and is substantially upregulated in hypertensive patients in therapy with ACE-i and ARBs. ${ }^{37}$ Respiratory symptoms related with SARS-CoV-2, tend to be more severe in patients with pre-existing CVD, often treated with RAAS inhibitors. Starting from this evidence, some authors ${ }^{38,} 39$ advanced the hypothesis that diabetic hypertensive patients treated with ACE-i and ARBs could be at higher risk of developing COVID-19 due to the increased specific receptor (ACE2) expression, and suggested a therapeutic shift to calcium channel blockers (CCB).

Starting from the evidences about inflammatory mechanisms underlying ARDS pathogenesis during 2003 SARS-CoV emergency ${ }^{23}$ it seems that, although the protective role of ACE 2 up-regulation could seem paradoxical, it may protect patients against ALI rather than putting patients at higher risk to develop ARDS. ${ }^{32}$

Currently, the available evidence comes only from observational studies with many potential confounding factors, although often involving a large number of patients.

A database of 169 Asian, European and North American hospitals (Surgical Outcomes Collaborative registry) on 8910 patients with COVID-19 revealed no association between ARBs administration and in-hospital mortality (OR 1,23-95\% CI: 0.87-1.74), while an increased survival was shown for patients taking ACE-i (OR $0.33-95 \%$ CI: $0.20-0.54)$. Similar results were 


\section{COPYRIGHT $^{\circledR} 2020$ EDIZIONI MINERVA MEDICA}

ACE-INHIBITORS, ARBS AND SARS-COV-2

INFUSINO

confirmed in the subgroup analysis of hypertensive patients. ${ }^{40}$

Moreover, in a retrospective study conducted in 9 hospitals of the Hubei province (China), data on 1128 hypertensive patients hospitalized for COVID-19 (188 on therapy and 940 not on therapy with ACE-i nor ARBs) were analyzed. In this study population, inpatient use of ACEi/ARBs were associated with lower risk of allcause mortality. ${ }^{41}$

Reynolds et al. conducted a study to verify the relationship between a previous therapy with different cardiovascular drugs and the likelihood of a positive SARS-CoV-2 test or severe COVID-19 disease. Among 12,594 patients tested for SARS-CoV-2, 46.8\% were positive and $17.0 \%$ developed severe illness. 4357 patients (34.6\%) had a previous history of hypertension and $59.1 \%$ among the latter developed positivity to the test with $24.6 \%$ of severe illness. Authors found no association between therapy with ACE$i$ and ARBs, as well as other cardiovascular drug therapy, and the likelihood of developing positivity for COVID-19 or severe disease. ${ }^{42}$

A case-control study by Mancia et al. involved 6272 case patients with SARS-CoV-2 infection and 30,759 controls according to sex, age, and place of residence in Northern Italy. It demonstrated that COVID-19 patients had a higher prevalence of cardiovascular disease and cardiovascular drug therapy including ACE-i or ARBs, compared to the control group. However, multi- variate analysis showed no association between the risk of Covid-19 and ACE-i or ARBs. ${ }^{43}$

Several other observational studies have not shown a worse prognosis in COVID-19 patients receiving RAAS inhibitors, rather some studies have shown a clinical benefit. ${ }^{44-48}$

A recent meta-analysis by Pirola and Sookoian, 49 including 24,676 COVID-19 patients enrolled in 16 studies, reported a protective effect of therapy with RAAS modulating drugs $(23 \%$ reduced risk of death and/or critical disease). In drug-specific analysis, therapy alone with ACE-i explained the result (OR 0.652; 95\% CI: 0.478 to 0.891 ) while the effect of ARBs alone did not determine any influence on the outcome of COVID-19.49

Further, a controlled study is currently recruiting patients to test the effects of intravenous administration with recombinant human angiotensin-converting enzyme 2 (RhACE2-APN01) in COVID-19 patients. The primary endpoint is composed by all cause-death or invasive mechanical ventilation up to 28 days or hospital discharge; September 2020 is the estimated date for completion. Considering the available evidence, it is not easy to predict the effect of the experimental drug on viral clearance and cardiovascular system. ${ }^{50}$

Some cardiovascular scientific societies published their position statement about the possible discontinuation of ACE-i and/or ARBs in hypertension and/or heart failure in the context of COVID-19 outbreak (Table I). The European

TABLE I.-Main recommendations by scientific community regarding the possible discontinuation of ACE-inhibitors and/or ARBs in hypertension and/or heart failure in the context of COVID-19 outbreak.

\begin{tabular}{|c|c|c|}
\hline & Hypertension recommendation & Heart failure recommendation \\
\hline $\begin{array}{l}\text { SIC statement } \\
\text { (11 March 2020) }\end{array}$ & Switch to other drugs is controversial & $\begin{array}{l}\text { Benefit from their discontinuation is not } \\
\text { documented }\end{array}$ \\
\hline $\begin{array}{l}\text { ESH statement } \\
\quad(12 \text { March 2020) }\end{array}$ & $\begin{array}{l}\text { Available data do not support a differential use } \\
\text { of RAS blockers }\end{array}$ & Not mentioned \\
\hline $\begin{array}{l}\text { ESC statement } \\
(13 \text { March 2020) }\end{array}$ & $\begin{array}{l}\text { Lack of any evidence regarding their harmful } \\
\text { effect }\end{array}$ & Not mentioned \\
\hline $\begin{array}{l}\text { SIIA statement } \\
\text { (13 March 2020) }\end{array}$ & $\begin{array}{l}\text { Lack of any evidence regarding their harmful } \\
\text { effect }\end{array}$ & Not mentioned \\
\hline $\begin{array}{l}\text { HFSA/ACC/AHA Statement } \\
\text { (17 March 2020) }\end{array}$ & $\begin{array}{l}\text { No data available demonstrating benefit or } \\
\text { adverse outcomes }\end{array}$ & $\begin{array}{l}\text { No data available demonstrating benefit or } \\
\text { adverse outcomes }\end{array}$ \\
\hline $\begin{array}{l}\text { COVID-19 and Cardiology } \\
\text { ESC guidelines } \\
\text { (10 June 2020) }\end{array}$ & $\begin{array}{l}\text { No evidence to suggest that ACE-i/ARBs } \\
\text { increase the risk of infection and there is no } \\
\text { reason to discontinue }\end{array}$ & $\begin{array}{l}\text { No data regarding increased risk of infection; } \\
\text { withdrawal in HF patients may increase HF } \\
\text { worsening. }\end{array}$ \\
\hline
\end{tabular}

ACC: American College of Cardiology; AHA: American Heart Association; ESC: European Society of Cardiology; ESH: European Society of Hypertension; HFSA: Heart Failure Society of America; RAS: renin-angiotensin system; SIC: Società Italiana di Cardiologia; SIIA: Società Italiana dell'Ipertensione Arteriosa. 


\section{COPYRIGHT $^{\circledR} 2020$ EDIZIONI MINERVA MEDICA}

Cardiology Society (ESC), the Italian Cardiology Society (Società Italiana di Cardiologia, SIC), the Italian Hypertension Society (Società Italiana dell'Ipertensione Arteriosa, SIIA), the European Society of Hypertension (ESH), and the Heart Failure Society of America (HFSA)/American College of Cardiology (ACC)/American Heart Association (AHA) highlighted the lack of any evidence regarding the harmful effect of ACE-i and ARBs in the context of COVID-19 outbreak. The main recommendation remains to not discontinue drug therapy in hypertensive and/or heart failure patients, both infected and at risk of critical illness in case of SARS-CoV-2 infection. ${ }^{51-56}$

\section{Conclusions}

Although ACE 2 appears to be the leading actor, the relationship between the cardiovascular system and COVID-19 is not yet well understood. Much caution should be exercised in the management of drugs that affect the renin angiotensin system, as there is no solid information. According to current evidences, official recommendations by ESC, ESH, SIC, SIIA and HFSA/ACC/ AHA recommend to not discontinue therapy in any setting of patient. We need large randomized clinical trials that can give more certainties, with the hope of finding a mechanism to hinder the SARS-CoV-2 pathway.

\section{References}

1. WHO. Coronavirus disease (COVID-19) dashboard; 2020 [Internet] Available from: https://experience.arcgis.com/exp erience/685d0ace521648f8a5beeee1b9125cd [cited 2020, Jun 9].

2. Wu Z, McGoogan JM. Characteristics of and Important Lessons From the Coronavirus Disease 2019 (COVID-19) Outbreak in China: Summary of a Report of 72314 Cases From the Chinese Center for Disease Control and Prevention. JAMA 2020;323:1239-42.

3. Kuba K, Imai Y, Rao S, Gao H, Guo F, Guan B, et al. A crucial role of angiotensin converting enzyme 2 (ACE2) in SARS coronavirus-induced lung injury. Nat Med 2005;11:875-9.

4. Letko M, Marzi A, Munster V. Functional assessment of cell entry and receptor usage for SARS-CoV-2 and other lineage B betacoronaviruses. Nat Microbiol 2020;5:562-9. [Chinese].

5. Sun ML, Yang JM, Sun YP, Su GH. [Inhibitors of RAS Might Be a Good Choice for the Therapy of COVID-19 Pneumonia]. Zhonghua Jie He He Hu Xi Za Zhi 2020;43:219-22.
6. Fountain JH, Lappin SL. Physiology, Renin Angiotensin System. Treasure Island , FL: StatPearls Publishing; 2020.

7. ACE2 angiotensin I converting enzyme 2 [Homo sapiens (human)]. NCBI; 2020 [Internet]. Available from: https:// www.ncbi.nlm.nih.gov/gene? $\mathrm{Db}=$ gene \&Cmd=DetailsSearch \&Term=59272 [cited 2020, March 14].

8. Santos RA, Simoes e Silva AC, Maric C, Silva DM, Machado RP, de Buhr I, et al. Angiotensin-(1-7) is an endogenous ligand for the $\mathrm{G}$ protein-coupled receptor Mas. Proc Natl Acad Sci USA 2003;100:8258-63.

9. Santos RA, Frézard F, Ferreira AJ. Angiotensin-(1-7): blood, heart, and blood vessels. Curr Med Chem Cardiovasc Hematol Agents 2005;3:383-91.

10. Imai Y, Kuba K, Ohto-Nakanishi T, Penninger JM. Angiotensin-converting enzyme 2 (ACE2) in disease pathogenesis. Circ J 2010;74:405-10.

11. Heurich A, Hofmann-Winkler H, Gierer S, Liepold T, Jahn O, Pöhlmann S. TMPRSS2 and ADAM17 cleave ACE2 differentially and only proteolysis by TMPRSS 2 augments entry driven by the severe acute respiratory syndrome coronavirus spike protein. J Virol 2014;88:1293-307.

12. Hicks BM, Filion KB, Yin H, Sakr L, Udell JA, Azoulay L. Angiotensin converting enzyme inhibitors and risk of lung cancer: population based cohort study. BMJ 2018;363:k4209.

13. Ye R, Liu Z. ACE2 exhibits protective effects against LPS-induced acute lung injury in mice by inhibiting the LPSTLR4 pathway. Exp Mol Pathol 2020;113:104350.

14. Dijkman R, Jebbink MF, Deijs M, Milewska A, Pyrc K, Buelow $\mathrm{E}$, et al. Replication-dependent downregulation of cellular angiotensin-converting enzyme 2 protein expression by human coronavirus NL63. J Gen Virol 2012;93:1924-9.

15. Sodhi CP, Wohlford-Lenane C, Yamaguchi Y, Prindle T, Fulton WB, Wang $\mathrm{S}$, et al. Attenuation of pulmonary ACE2 activity impairs inactivation of des-Arg9 bradykinin/BKB1R axis and facilitates LPS-induced neutrophil infiltration. Am J Physiol Lung Cell Mol Physiol 2018;314:L17-31.

16. Turner AJ, Hiscox JA, Hooper NM. ACE2: from vasopeptidase to SARS virus receptor. Trends Pharmacol Sci 2004;25:291-4.

17. Hamming I, Timens W, Bulthuis ML, Lely AT, Navis G, van Goor H. Tissue distribution of ACE2 protein, the functional receptor for SARS coronavirus. A first step in understanding SARS pathogenesis. J Pathol 2004;203:631-7.

18. Zhao Y, Zhao Z, Wang Y, Zhou Y, Ma Y, Zuo W. Singlecell RNA expression profiling of ACE2, the putative receptor of Wuhan 2019-nCov. bioRxiv 2020 [Internet]. Available from: https://www.biorxiv.org/content/10.1101/2020.01.26.9 19985v1.full [cited 2020, Jun 6].

19. Jia HP, Look DC, Shi L, Hickey M, Pewe L, Netland J, et al. ACE2 receptor expression and severe acute respiratory syndrome coronavirus infection depend on differentiation of human airway epithelia. J Virol 2005;79:14614-21.

20. Li W, Zhang C, Sui J, Kuhn JH, Moore MJ, Luo S, et al. Receptor and viral determinants of SARS-coronavirus adaptation to human ACE2. EMBO J 2005;24:1634-43.

21. Cai, G. Tobacco-Use Disparity in Gene Expression of ACE2, the Receptor of 2019-nCov. Preprints 2020. [Epub ahead of print].

22. Cao Y, Li L, Feng Z, Wan S, Huang P, Sun X, et al. Comparative genetic analysis of the novel coronavirus (2019nCoV/SARS-CoV-2) receptor ACE2 in different populations. Cell Discov 2020;6:11.

23. Imai Y, Kuba K, Rao S, Huan Y, Guo F, Guan B, et al. Angiotensin-converting enzyme 2 protects from severe acute lung failure. Nature 2005;436:112-6. 


\section{COPYRIGHT $^{(} 2020$ EDIZIONI MINERVA MEDICA}

24. Vangjeli C, Dicker P, Tregouet DA, Shields DC, Evans A, Stanton AV; MORGAM project. A polymorphism in ACE2 is associated with a lower risk for fatal cardiovascular events in females: the MORGAM project. J Renin Angiotensin Aldosterone Syst 2011;12:504-9.

25. Yang W, Huang W, Su S, Li B, Zhao W, Chen S, et al. Association study of ACE2 (angiotensin I-converting enzyme 2) gene polymorphisms with coronary heart disease and myocardial infarction in a Chinese Han population. Clin Sci (Lond) 2006;111:333-40.

26. Burrell LM, Harrap SB, Velkoska E, Patel SK. The ACE2 gene: its potential as a functional candidate for cardiovascular disease. Clin Sci (Lond) 2013;124:65-76.

27. Berletch JB, Yang F, Xu J, Carrel L, Disteche CM. Genes that escape from X inactivation. Hum Genet 2011;130:237-45.

28. Messerli FH, Bangalore S, Bavishi C, Rimoldi SF. Angiotensin-Converting Enzyme Inhibitors in Hypertension: To Use or Not to Use? J Am Coll Cardiol 2018;71:1474-82.

29. Chobanian AV. Editorial: angiotensin inhibition. N Engl J Med 1974;291:844-5.

30. Ferrario CM, Jessup J, Chappell MC, Averill DB, Brosnihan KB, Tallant EA, et al. Effect of angiotensin-converting enzyme inhibition and angiotensin II receptor blockers on cardiac angiotensin-converting enzyme 2. Circulation 2005;111:2605-10.

31. Moskowitz DW, Johnson FE. The central role of angiotensin I-converting enzyme in vertebrate pathophysiology. Curr Top Med Chem 2004;4:1433-54.

32. Gurwitz D. Angiotensin receptor blockers as tentative SARS-CoV-2 therapeutics. Drug Dev Res 2020. [Epub ahead of print]

33. Use of angiotensin receptor blockers such as Telmisartan, Losartsan in nCoV Wuhan Corona Virus infections - Novel mode of treatment. The BMJ; 2020 [Internet]. Available from: https://www.bmj.com/content/368/bmj.m406/rr-2 [cited 2020, Jun 14].

34. Sun ML, Yang JM, Sun YP, Su GH. [Inhibitors of RAS Might Be a Good Choice for the Therapy of COVID-19 Pneumonia]. Zhonghua Jie He He Hu Xi Za Zhi 2020;43:E014. [Chinese].

35. Ishiyama $Y$, Gallagher PE, Averill DB, Tallant EA, Brosnihan $\mathrm{KB}$, Ferrario CM. Upregulation of angiotensin-converting enzyme 2 after myocardial infarction by blockade of angiotensin II receptors. Hypertension 2004;43:970-6.

36. Wan Y, Shang J, Graham R, Baric RS, Li F. Receptor Recognition by the Novel Coronavirus from Wuhan: an Analysis Based on Decade-Long Structural Studies of SARS Coronavirus. J Virol 2020;94:e0127-20.

37. Li XC, Zhang J, Zhuo JL. The vasoprotective axes of the renin-angiotensin system: physiological relevance and therapeutic implications in cardiovascular, hypertensive and kidney diseases. Pharmacol Res 2017;125(Pt A):21-38.

38. Fang L, Karakiulakis G, Roth M. Are patients with hypertension and diabetes mellitus at increased risk for COVID-19 infection? [published correction appears in Lancet Respir Med. 2020 Jun;8(6):e54]. Lancet Respir Med 2020;8:e21.

39. Re: Preventing a covid-19 pandemic: ACE inhibitors as a potential risk factor for fatal Covid-19. The BMJ; 2020 [Internet]. Available from: https://www.bmj.com/content/368/bmj. m810/rr-2 [cited 2020, Jun 14].

40. Mehra MR, Desai SS, Kuy S, Henry TD, Patel AN. Cardiovascular Disease, Drug Therapy, and Mortality in Covid-19. N Engl J Med 2020. [Epub ahead of print]

41. Zhang P, Zhu L, Cai J, Lei F, Qin JJ, Xie J, et al. Association of Inpatient Use of Angiotensin-Converting Enzyme
Inhibitors and Angiotensin II Receptor Blockers With Mortality Among Patients With Hypertension Hospitalized With COVID-19. Circ Res 2020;126:1671-81.

42. Reynolds HR, Adhikari S, Pulgarin C, Troxel AB, Iturrate $\mathrm{E}$, Johnson $\mathrm{SB}$, et al. Renin-Angiotensin-Aldosterone System Inhibitors and Risk of Covid-19. N Engl J Med 2020;382:2441-8.

43. Mancia G, Rea F, Ludergnani M, Apolone G, Corrao G. Renin-Angiotensin-Aldosterone System Blockers and the Risk of Covid-19. N Engl J Med 2020;382:2431-40.

44. Felice C, Nardin C, Di Tanna GL, Grossi U, Bernardi E, Scaldaferri L, et al. Use of RAAS inhibitors and risk of clinical deterioration in COVID-19: results from an Italian cohort of 133 hypertensives. Am J Hypertens 2020. [Epub ahead of print]

45. Meng J, Xiao G, Zhang J, He X, Ou M, Bi J, et al. Reninangiotensin system inhibitors improve the clinical outcomes of COVID-19 patients with hypertension. Emerg Microbes Infect 2020;9:757-60.

46. Bean DM, Kraljevic Z, Searle T, Bendayan R, Kevin O G, Pickles A, et al. ACE-inhibitors and Angiotensin-2 Receptor Blockers are not associated with severe SARS-COVID19 infection in a multi-site UK acute Hospital Trust. Eur J Heart Fail 2020. [Epub ahead of print]

47. Yang G, Tan Z, Zhou L, Yang M, Peng L, Liu J, et al. Effects of Angiotensin II Receptor Blockers and ACE (Angiotensin-Converting Enzyme) Inhibitors on Virus Infection, Inflammatory Status, and Clinical Outcomes in Patients With COVID-19 and Hypertension: A Single-Center Retrospective Study. Hypertension 2020;76:51-8.

48. Li J, Wang X, Chen J, Zhang H, Deng A. Association of Renin-Angiotensin System Inhibitors With Severity or Risk of Death in Patients With Hypertension Hospitalized for Coronavirus Disease 2019 (COVID-19) Infection in Wuhan, China. JAMA Cardiol 2020. [Epub ahead of print].

49. Pirola CJ, Sookoian S. Estimation of Renin-Angiotensin-Aldosterone-System (RAAS)-Inhibitor effect on COVID-19 outcome: A Meta-analysis. J Infect 2020;S01634453(20)30329-7. [Epub ahead of print]

50. Recombinant Human Angiotensin-converting Enzyme 2 (rhACE2) as a Treatment for Patients With COVID-19. ClinicalTrials.gov; 2020 [Internet]. Available from: https:// clinicaltrials.gov/ct2/show/study/NCT04335136 [cited 2020, Jun 14].

51. ESC Guidance for the Diagnosis and Management of CV Disease during the COVID-19 Pandemic. ESC; 2020 [Internet]. Available from: https://www.escardio.org/Education/COVID-19-and-Cardiology/ESC-COVID-19-Guidance [cited 2020, Jun 14].

52. HFSA/ACC/AHA Statement Addresses Concerns Re. Using RAAS Antagonists in COVID-19. American College of Cardiology; 2020 [Internet]. Available from: https://www.acc. org/latest-in-cardiology/articles/2020/03/17/08/59/hfsa-accaha-statement-addresses-concerns-re-using-raas-antagonistsin-covid-19 [cited 2020, Jun 14].

53. ESH statement on COVID-19. ESH; 2020 [Internet]. Available from: https://www.eshonline.org/spotlights/eshstatement-covid-19/ [cited 2020, Mar 12].

54. Farmaci antiipertensivi e rischio di COVID-19: il comunicato della SIIA. SIA; 2020 [Internet]. Available from: https://siia.it/notizie-siia/farmaci-antiipertensivi-e-rischio-dicovid-19-il-comunicato-della-siia/ [cited 2020, Jun 6].

55. Documento della SIC: guida clinica covid-19 per cardiologi. SIC; 2020 [Internet].Available from:https://www. sicardiologia.it/public/Documento-SIC-COVID-19.pdf [cited 2020, Jun 14]. 


\section{COPYRIGHT $^{(\odot)} 2020$ EDIZIONI MINERVA MEDICA}

INFUSINO

ACE-INHIBITORS, ARBS AND SARS-COV-2

56. Position Statement of the ESC Council on Hypertension on ACE-Inhibitors and Angiotensin Receptor Blockers. ESC; 2020 [Internet]. Available from: https://www.escardio.org/
Councils/Council-on-Hypertension-(CHT)/News/positionstatement-of-the-esc-council-on-hypertension-on-ace-inhibitors-and-ang [cited 2020, Jun 14].

Conflicts of interest.-The authors certify that there is no conflict of interest with any financial organization regarding the material discussed in the manuscript.

Authors' contributions.-All authors contributed equally to the manuscript and read and approved the final version of the manuscript. History._Article first published online: May 29, 2020. - Manuscript accepted: May 7, 2020. - Manuscript received: March 16, 2020. 